\title{
INCIDENCE OF MRSA ISOLATED FROM RETAIL MEAT AND MEAT HANDLERS IN TANTA CITY
}

\author{
Mona F. Eltalawy, Aml M. Ragab, Gamal, R. Hassb Elnaby \\ and Nermeen F. El Shopary \\ Animal Health Research Institute, Tanta Lab., Tanta, Egypt.
}

\begin{abstract}
sixty meat product samples represented by minced meat, burger, and sausage (20 of each) and 60 of their corresponding personnel hand swabs randomly collected from different supermarkets and retailers of different sanitation levels, in Tanta city, El Gharbia Province, Egypt and were bacteriologically analyzed to assess the prevalence of $S$. aureus and the resistant type (MRSA).The obtained results revealed that $S$. aureus could be isolated and identified from 60\%,20\% and 100 $\%$ and $40 \%, 40 \%$ and $100 \%$ of the examined minced meat, burger, and sausage and there swabs respectively. Meanwhile the percentages for the MRSA type in the same examined meat product samples were $40 \%, 40 \%, 60 \%$ and $40 \%, 5 \%$ and $15 \%$ respectively using the antibiogram testing method.

The polymerase chain reaction (PCR) was used for detection of the mecA gene that was detected in all isolated strains showed either complete or intermediate resistance in antibiotic sensitivity test.The critical question is whether the roles in some countries are enough to eliminate or reduce the global reservoirs of resistant pathogens and resistance genes. This may require more fundamental shifts in the way animals are raised to decrease disease susceptibility, so as to lower the use of antibiotics for all purposes in animal agriculture.
\end{abstract}

Keywords: MRSA, Meat products meat handlers, swabs and mecA gene 


\section{INTRODUCTION}

staphylococcus aureus is one of the major resistant pathogens in clinical practice. Methicillin-resistant Staphylococcus aureus (MRSA) is a critically important human pathogen, and attention has been paid recently to the potential role of food animals in human MRSA infection and colonization, the role of foodborne Contamination in human MRSA infection or colonization is currently unclear and much further study is required to elucidate this potential problem. One aspect that has to be considered is the amount of MRSA in contaminated meat. Previous studies have used enrichment culture techniques that can have a very low detection threshold; 12-15 CFU per $25 \mathrm{~g}$ in one study (de Boer et al. 2009). While the infectious dose of MRSA in meat (if meat is truly a potential source of infection) is not known.

Although meat and meat products have a high nutritive value, palatable, acceptable and desirable for many consumers, yet they may in many cases became a cause to induce food poisoning. The battle against bacterial food borne diseases is facing new challenges due to rapidly changing patterns of human consumption, the globalization of the food market and climate change. Today, consumers want more natural food products that are less processed, without preservatives, with low salt, sugar or fat contents, but with an extended shelf-life and high quality (Zink, 1997).

Staphylococcus aureus this facultative, gram positive , halo-tolerant bacterium readily colonizes skin, various mucosal surfaces, soft tissues, bone as well as indwelling medical devices is a formidable pathogen linked to many human diseases and has been implicated as causing severe morbidity and mortality worldwide (krakauer and stiles, 2013). 
Staphylococci are notorious for rapidly evolving resistance to many antibiotics. MRSA is defined as a strain of $S$. aureus that is resistant to a large group of antibiotics called $\beta$ lactams, that includes penicillins and cephalosporins. Penicillins and other $\beta$-lactam antibiotics kill bacterial cells by interfering with cell wall synthesis. Not long after penicillin was first used to treat human infections, $S$. aureus strains producing penicillinase (an enzyme that degrades penicillin) were detected and it is estimated that now $>80 \%$ of $S$. aureus produce penicillinase. Methicillin (meticillin), a $\beta$-lactam antibiotic that is not inactivated by penicillinase, was introduced in the late 1950s. But by 1961, there were reports of methicillin resistant staphylococci in a hospital in the United Kingdom Amachawadi et al. (2011). Methicillin resistance is caused by the presence of mecA gene, which encodes an additional $78 \mathrm{kDa}$ lowaffinity penicillin binding protein (PBP) 2a or PBP2' which has a low affinity for Blactam antibiotics (Davies et al. 2011). There has been a steady increase in the prevalence of MRSA all over the world.

Although epidemiology of MRSA (methicillin-resistant S. aureus) is currently being intensely studied, it should be noted that in most hospitals and geographic areas MSSA (methicillinsusceptible $S$. aureus) are responsible for a greater number of infections and are often also resistant to currently available $\beta$-lactam antibiotics, including penicillins, cephalosporins, carbapenems, and their derivatives and also for multiple classes of antibiotics and this is mediated by the mecA gene which encodes an altered penicillin-binding protein, located in the cell wall, that has a low affinity for $\beta$-lactam antibiotics. Since $\beta$-lactam antibiotics interfere with bacterial cell wall synthesis, this decreased binding of $\beta$-lactams renders them ineffective against MRSA. The mecA gene resides on a large heterogeneous mobile genetic element called the staphylococcal cassette chromosome (SCCmec) Seiler andBerendonk (2012). 
Food handlers have been implicated in a plethora of foodborne diseases. It has been reported that one of the important pathogens often transmitted via food contaminated by infected food handlers is S. aureus. This versatile pathogen is very well adapted to colonize the human skin and the human body provides some major ecological niches for this species. The anterior nares is the most frequent carriage site for $S$. aureus, none the less extra nasal sites typically harbor the organism including the skin, perineum and pharynx (Verkaiket al, 2011 and Wertheim et al,2005) and according to several, S. aureus is present in nasal passages or skin of about $50 \%$ of people and in intestines of about $20 \%$ of people in the general population Marshall and Levy (2011). Thus, asymptomatic food handlers may harbor S. aureus and can contaminate food during preparation Federation of Animal Science Societies (2010).

MRSA strains have been detected in meat and may also be present in a variety of other foods. The origin of these contaminants has been traced to infected / colonized food handlers in some outbreaks Moodley et al.(2011). Studies have demonstrated that meat can also become contaminated during slaughter and processing of animals carrying MRSA van Cleef et al.(2011).

MRSA has been detected in a variety of foods from countries in North America, Europe and Asia. Foods may be contaminated by human strains of MRSA present in meat processors and other food handlers. Meat may also be contaminated by MRSA carried in animals as demonstrated by a study following pigs from lairage through slaughter to commercial pork products while another study investigating MRSA on German cattle at slaughter and at several steps during processing found that $6 \%$ of cattle carcasses were positive on the slaughter line, $4.2 \%$ of meat samples during processing, and $3 \%$ of finished meat products tested positive Matlow et al.(2012). 
The present study was planned to investigate the occurrence of MRSA in retail meat products intended for direct consumption and also its occurrence in these products handlers. Moreover, the characterization of MRSA using simplex PCR was also investigated to give a brief image on its spread in Tanta city.

\section{MATERIALS AND METHODS}

Sampling: A total of 60 meat product samples represented by minced meat, burger and sausage and 60 samples of their corresponding handler swabs (20 of each) were randomly collected from different supermarkets and retailers of different sanitation levels, in Tanta city, El Gharbia Governorate, Egypt. Each sample was separately packed, identified and immediately transferred under sanitary precaution to the laboratory where they were subjected to the bacteriological examination within an hour of collection.

Preparation of samples: according to the method recommended by $I C M S F,(1978)$.

Detection of $\boldsymbol{S}$. aureus: The samples were evaluated immediately upon arrival using aseptic techniques. All samples were cultured and their biochemical properties were evaluated using the methods described by (APHA, 1992). Ten grams portion of each sample were added to 90 $\mathrm{ml}$ of sterile phosphate buffered saline.

A $0.1 \mathrm{ml}$ aliquot of the homogenate was dropped on previously dried surface of Baird Parker agar plates (Difco Laboratories, Detroit, Michigan, USA). The swabs were also inoculated onto these media types. These set up were incubated aerobically at $37^{\circ} \mathrm{C}$ for 24 hours, after which the plates were read. 
Suspected colonies (black, shiny convex colonies, 1-1.5 $\mathrm{mm}$ in diameter and surrounded by clear halo zone) were subcultured on blood agar plate (Difco Laboratories, Detroit, Michigan, USA) and incubated for 24 hours at $37^{\circ} \mathrm{C}$.

To identify $S$. aureus, All of the isolates were confirmed as Staphylococcus genus

by different biochemical tests such as Gram staining, catalase and oxidase. Catalase, Gram positive and oxidase negative isolates were defined as Staphylococcus. Isolates indicating Staphylococcus characteristics were further analyzed by fermentation in manitol salt agar medium, DNase and coagulase tests. All S. aureus were DNase and coagulase positive and fermented manitol tests were performed on suspected colonies according to Quinn et al. (2002).

\section{Antimicrobial Susceptibility Testing:}

The positive isolates were suspended in saline solution and $100 \mathrm{~mL}$ was inoculated in brain heart infusion (BHI) broth containing 6.5\% $\mathrm{NaCl}$, and incubated at $35^{\circ} \mathrm{C}$ for 24 and poured on the surface of Mueller Hinton agar plates (Oxoid) then the antibiotic disks were sited and incubated at $37^{\circ} \mathrm{C}$ for 24 hours.

Antibiotic disks used :Oxacillin $(1 \mu \mathrm{g})$,(by disc diffusion method according to the guidelines of Clinical and Laboratory Standards Institute (CLSI) (Wikler,2006).

\section{PCR amplification of the mecA gene:}

DNA extraction: was performed by QIAamp DNA minikit (QIAGEN). The mecA gene was amplified using the primers as described by Geha et al., (1994) and given in (Table 1). A $50 \mu 1$ PCR reaction consisted of plus $45 \mu$ l of master mix containing PCR buffer (1X), dNTP 
mix $(0.2 \mathrm{mM}$ of each), primer $(0.5 \mu \mathrm{M})$, Taq DNA polymerase $(0.25 \mathrm{U})$, and $\mathrm{MgCl} 2(1.5 \mathrm{mM})$ with $5 \mu \mathrm{L}$ of template DNA. Cycling conditions were - hot start at $94^{\circ} \mathrm{C}$ for 4 minutes followed by 30 cycles of denaturation at $94{ }^{\circ} \mathrm{C}$ for 45 seconds, annealing at $50{ }^{\circ} \mathrm{C}$ for 45 seconds, and extension at $72^{\circ} \mathrm{C}$ for 1 minute and final extension step at $72{ }^{\circ} \mathrm{C}$ for 3 minutes. PCR products were visualized on $1.5 \%$ agarose gel with ethidium bromide dye under UV transilluminator. Amplicons of $310 \mathrm{bp}$ were consistent with mecA gene amplification (Figure 3).

Table (1): Primer and its sequence (Geha et al.,1994):

\begin{tabular}{|c|c|c|}
\hline Primer Sequence & Position & Product size (bp) \\
\hline \hline Forward5'-GTA GAA ATG ACT GAA CGT CCG ATA A-3' & $318-342$ & 310 \\
Reverse5'-CCA ATT CCA CAT TGT TTC GGT CTA A-3' & $603-627$ & \\
\hline
\end{tabular}

\section{RESULTS}

Table (2): Prevalence of $S$.aureus in the examined meat product samples $(\mathrm{n}=20$,each):

\begin{tabular}{|c|c|c|}
\hline \multirow{2}{*}{ Product } & \multicolumn{2}{|c|}{ positive samples } \\
\hline & No & $\%$ \\
\hline Minced meat & 12 & 60 \\
\hline Burger & 4 & 20 \\
\hline Sausage & 20 & 100 \\
\hline
\end{tabular}

Table (3): Prevalence of $S$.aureus in the examined meat product handlers swabs samples $\quad(n=20$,each $)$

\begin{tabular}{|c|c|c|}
\hline \multirow{2}{*}{ Product } & \multicolumn{2}{|c|}{ positive samples } \\
\hline & No & $\%$ \\
\hline Minced meat & 8 & 40 \\
\hline Burger & 8 & 40 \\
\hline Sausage & 20 & 100 \\
\hline
\end{tabular}


Mona F. Eltalawy et., al.

Table (4): Prevalence of MRSA in the examined meat product and meat handlers swabs samples $(\mathrm{n}=20$, each)

\begin{tabular}{|c|c|c|c|c|}
\hline \multirow{2}{*}{ Product } & \multicolumn{2}{|c|}{ Positive for product } & \multicolumn{2}{|c|}{ positive for handler } \\
\hline & No & $\%$ & No & $\%$ \\
\hline Minced meat & 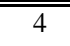 & 20 & 8 & 40 \\
\hline Burger & 4 & 20 & 1 & 5 \\
\hline Sausage & 12 & 60 & 16 & 15 \\
\hline
\end{tabular}

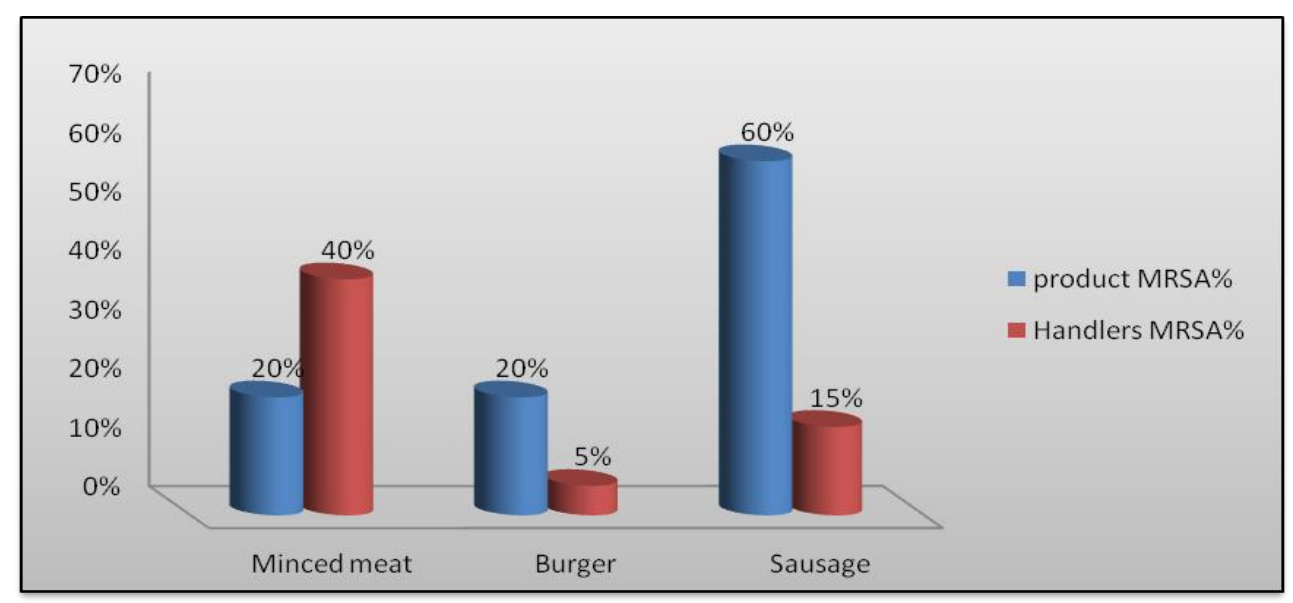

Fig. (1): prevalence of $S$. aureus and MRSA type in examined meat products and their corresponding handlers.

Table (5): Frequency of Antibiotic Resistance of MRSA Strains.(n=20)

\begin{tabular}{|c||c||}
\hline \multicolumn{1}{|c||}{ Oxacillin antibiotic disk } & MRSA No. (\%) \\
\hline \hline Meat product samples & $12(60 \%)$ \\
\hline \hline Minced meat & $9(45 \%)$ \\
\hline Burger & $13(65 \%)$ \\
\hline Sausage & \\
\hline \hline Handlers swabs $\quad$ Minced meat & $4(20 \%)$ \\
\hline \hline Burger & $4(20 \%)$ \\
\hline Sausage & $8(40 \%)$ \\
\hline
\end{tabular}

$\overline{\text { Kafrelsheikh Vet. Med. J. Vol. } 13 \text { No. } 1 \text { (2015) }}$ 


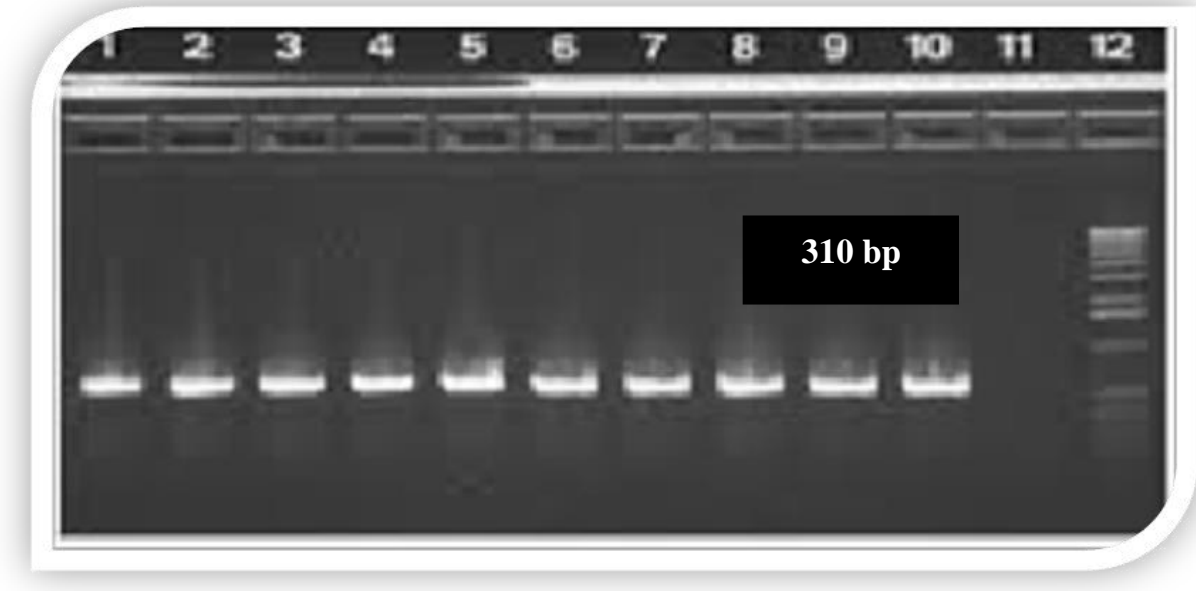

Fig. (2): PCR results of $S$. aureus (MRSA type) isolates for the detection of mecA gene in 1.5\% agarose (12: 100bp ladder,1 control positive $S$. aureus with mecA gene 2-10 positives for mecA gene, 11: control negative isolate for $m e c A$ gene.in different examined meat product samples and their corresponding handlers).

\section{DISCUSSION}

Indeed, S. aureus is an important health and economical concern throughout the world, from a biodefense respective spanning decades of research (krakauer and stiles, 2013). MRSA have spread worldwide and are now the most commonly identified antibiotic-resistant bacteria in hospitals in Europe, the Americas, North Africa, and the Middle- and Far-East Smith and Pearson (2011). Approximately 478,000 hospitalizations in the U.S. in 2005 were associated with S. aureus infections and $58 \%$ of those $(278,000)$ were caused by MRSA Fluit (2012). MRSA is estimated to cause illness in more than 150,000 persons annually in healthcare facilities in the European Union Castillo Neyra (2012). 
From the results achieved in Table (2) it is evident that $S$. aureus could be isolated from 12 out of 20 minced meat samples at a rate of 5 (60\%) which is higher than that found by El-jakee et al. (2013). While in burger samples (4/20) was $20 \%$, and this result was higher than that found by Youssef et al. (1985) while completely agree with that told by Eldaly et al.(2014). On the other side S. aureus was isolated from all the 20 examined sausage samples $(100 \%)$ such results were nearly coincide with that reported by Khalil et al. (2001). however, lower results were reported by Mousa et al. (1993). While by talking about the results achieved from the swabs taken from each aforementioned sample handler, Table (3) illustrated that $s$. aureus was found by an incidence of $40 \%$ in minced meat and burger handlers swabs and by $100 \%$ in the examined swabs taken from sausage handlers examined samples

According to several studies, approximately $50 \%$ of people in the general population are carriers of S. aureus Marshall and Levy (2011). However, CDC estimates that only about $1.5 \%$ of the population are carriers of MRSA.

From the aforementioned results, It is noticed that there was a significant increase in the prevalence of $S$. aureus in the examined samples of minced meat and sausage, compared with burger samples. This could be attributed to unsanitary environmental conditions, poor personal hygiene practices under which these products are produced.

During sample collection from the butchers, questionnaires were shared to obtain such relevant information as butchers' age, duration in the business of handing meat, marital status, habits, literacy and alternative occupation of each butcher among others. This information was relevant in the analysis and interpretation of the research findings. 
MRSA, like methicillin-susceptible $S$. aureus, can cause a range of infections from relatively mild skin infections to life threatening invasive bloodstream infections, pneumonia, central nervous system infections, and pericarditis. MRSA has been a chronic problem in hospitals and long-term care facilities for over 40 years, causing severe infections, particularly in patients in surgical wards and intensive care units. Infections acquired in the community typically affect skin and soft tissues, causing mild to severe symptoms. These infections often occur in healthy younger people without the usual risk factors for healthcareaquired MRSA, and infections often recur after treatment. Severe, invasive community-associated MRSA infections, including pneumonia, also occur Greenen et al. (2010).

From the results achieved in Table (4) it is evident that the incidence of MRSA type percentages in the examined minced meat, burger and sausage samples were 20\%,20\%and 60\% while the corresponding results from their handlers swabs (giving the same gene of resistance mecA gene as it is shown in figure 2 by PCR) were $40 \%, 5 \%$ and $15 \%$ respectively after they were isolated,identified and confirmed by antibiogram testing that declared that the resistance of the tested isolates and showed complete to moderate resistance for Oxacillin by a percentage of 60,45 and $65 \%$ in the $S$. aureus isolated from minced meat, burger and sausage samples while that from these handlers products were equal in minced meat and burger $(20 \%)$ but more resistance percentage was achieved by sausage handlers swabs (40\%) (Table 5), Such findings substantiate what has been reported by de Boer et al. ( 2009) (5 and 9\% in various meats), Khanna et al. (2007), Smith et al. (2008) and Eldaly et al. (2014) and lower than that found by $P \boldsymbol{u}$ et al.( 2009) (11\% in minced meat). 
Care should be taken in comparing prevalence data between different studies. The method used in this study for qualitative culture is able to consistently recover small numbers of MRSA in meat (Weese et al., 2009) but there are no standardized culture methodologies. Therefore, our results and other studies should mainly be taken to indicate that MRSA can be regularly found in different meat products and its handlers in many regions, without an attempt to compared prevalence between different studies.

Currently, isolation of MRSA from food animals has raised concern about the potential for food borne transmission (Davies et al., 2011 and Bos et al. 2012). This is because the state of health of animals prior to slaughtering and the prevailing circumstances in the slaughter house can contribute to the overall quality of meat from such animals (Stefani et al., 2012). This therefore projects great possibilities of MRSA colonization and transmission to humans, particularly those in close and frequent contact with animals and/or their products via the nature of their occupation or keeping animals as pets (WHO 2011) and Otter and French 2012) and Pets can acquire MRSA from humans and also be a potential reservoir for human MRSA infection. Similar MRSA strains have been detected in dogs and their owners, but surveys of dogs or humans colonized with MRSA have demonstrated that only a small number of human-dog pairs are infected with the same MRSA strain (United States Department of Agriculture. National Agricultural Statistics Service. 2007) that is why we should get rid of such pets in the slaughter house and the food markets at all.

Some data indicate that host genetic factors (Davies 2012) and competing microflora Marshall and Levy (2011) may affect persistence of colonization by $S$. aureus. A review of published data revealed that, 
overall, nasal, inguinal or axillary colonization with $S$. aureus was associated with a four-fold increase in serious infections (Baquero 2012). Asymptomatic carriage or colonization of individuals with $S$. aureus may be a risk factor for person-to-person transmission of these bacteria and for contamination of food.

The probability of ingestion of MRSA causing enteric disease is low, given the pathophysiology of staphylococcal food poisoning (ingestion of preformed enterotoxins), although it is plausible that ingestion could result in gastrointestinal colonization and the potential for subsequent extra-intestinal infection or transmission. Touching ones nose after handling contaminated meat could believably result in nasal colonization and contact of contaminated meat with skin lesions could potentially result in infection.

\section{CONCLUSION}

Microbial population that comes in contact with fresh meat during slaughtering, dressing and processing presents a challenging problem to the meat industry. Also the high prevalence of MRSA in retail meat products and their handlers achieved in this study cant indicate which of them is accused for MRSA spreading as it exists in them so, we only can tell that they play the same role in transmitting the microorganism along the food processing chain and consequently, more and more spreading .The condition of the animals prior to slaughter, sanitary condition of the slaughtering environment, and slaughtering materials also contribute to MRSA carriage of meat and butchers. This is of public health importance as it may play a potential role in transmitting the organism between animals and humans as well as to the community. So we could recommend advocating PCR for $m e c A$ gene on a regular basis for detecting methicillin resistance in $\mathrm{S}$. aureus isolates isolated from mecA gene was detected among all MRSA isolates 


\section{REFERENCES}

- A.P.H.A.(American public Health Association)(1992): Compendium of methods for the microbiological examination of foods, $3^{\text {rd }} \mathrm{Ed}$ Washington, D.C.,USA.

- Amachawadi, R.G.; Shelton, NW and Shi X, (2011): Selection of Fecal Enterococci Exhibiting tcrB-Mediated Copper Resistance in Pigs Fed Diets Supplemented with Copper. Applied and Environmental Microbiology 77(16):5597-5603

- Baquero Foin (2012): On the Shifting Balance: the Case of Staphylococcus aureus CC398. mBio 3(2):1-2.

- Beneke B, Klees S, Stührenberg B, Fetsch A, Kraushaar B, and Tenhagen BA. 2011. Prevalence of methicillinresistant Staphylococcus aureus in a fresh meat pork production chain. J Food Prot 74:126-129

- Bos ME, Graveland H, Portengen L, Wagenaar JA, and Heederik DJ. 2012. Livestock associated MRSA prevalence in veal calf production is associated with farm hygiene, use of antimicrobials, and age of the calves. Preventive Veterinary Medicine doi:10.1016/j.prevetmed.2012.01.002.

- Castillo Neyra, R, Vegosen L, Davis MF, Price L, and Silbergeld EK. 2012. Antimicrobial-resistant Bacteria: An Unrecognized Workrelated Risk in Food Animal Production. Safety and Health at Work 3:85-91. 125

- Davies PR, Wagstrom EA, and Bender JB. 2011. Letter to the Editor, Centers for Disease Control and Prevention. Lethal Necrotizing Pneumonia Caused by an ST398 Staphylococcus aureus Strain. 17(6):1-5. 
- Davies P. 2012. Livestock Associated MRSA. Power point accessed 1-25 13. http://www.youtube.com/watch?v=W9_7h6aJm1w.

- de Boer, E., Zwartkruis-Nahuis, J.T., Wit, B., Huijsdens, X., de Neeling, A., Bosch, T., van Oosterom, R.A., Vila, A. (2009): Prevalence of methicillin-resistant Staphylococcus aureus in meat. Int J Food Microbiol 134, 52-56.

- EI-Jakee, J.;Marouf, S.A.; Ata, N.S.; Abdel-Rahman, E.H.; Abd El-Moez, Sh.I.; Samy, A.A and El-Sayed, W.E (2013): Rapid Method for Detection of Staphylococcus aureusEnterotoxins in Food j. Global Veterinaria 11 (3): 335-341.

- Eldaly A., El Shopary F. and HassbElnaby R. (2014): Prevalence of methicillin-resistant S. aureus (MRSA) in Retail Meat products in El-Gharbia Province, Egypt Zagazig

- Federation of Animal Science Societies (2010): Antibiotics in Animals and People Webinar. fass.org

- Fluit AC. 2012. Livestock-associated Staphylococcus aureus Accepted Article, doi: 10.1111/j.1469-0691.2012.03846.x

- Geha D.J.;Uhl J.R.;GustaferroC.A.andPersing D.H. (1994): Multiplex PCR for the identification of methicillinresistant Staphylococci in the clinical laboratory. J. Clin .Microbiol. 1994;32:1768-72.

- Graveland H, Duim B, van Duijkeren E, Heederik D, and Wagenaar JA. 2011. Livestock associated methicillin resistant Staphylococcus aureus in animals and humans. International Journal of Medical Microbiology 301:630-634 
- Greenen PL, Blaak H, Koene MGJ, 2010. Antimicrobial resistance transmissible from food animals to humans - a risk profile. Dutch Society for Veterinary Epidemiology and Economics VEEC, Socially Responsible Animal Disease Control, Proceedings 23rdAnnual Meeting Central Veterinary Institut.

- International Commission on Microbiological Specification for Food (ICMSF) (1978): Microorganisms in foods, their significance and method of enumeration . $2^{\text {nd }} \mathrm{Ed}$.Univ. of Toronto press . Toronto Canada.

- Jones TF, Kellum ME., Porter SS, Bell M, and Schaffner W. 2002. An outbreak of community-acquired foodborne illness caused by methicillin-resistant Staphylococcus aureus.Emerg Infect Dis 8:82-84

- Khalil E.M.; Zaky; N.M; Yossef M. G. and Riyad, Y.M. (2001): Chemical and Microbial Quality of some meat products .Egyptian. J. of Nutrition, 16: (2)119-126.

- Khanna T.; Friendship R.; Dewey C. and Weese J.S. (2007): Methicillin resistant Staphylococcus aureuscolonization in pigs and pig farmers. Vet Microbiol. 128, 298-303.

- Kluytmans J, van Leeuwen W, Goessens W, Hollis R, Messer S, Herwaldt L, Bruining H, Heck M, Rost J, van Leeuwen $N$, van Belkum A, and Verbrugh H. 1995. Foodinitiated outbreak of methicillin-resistant Staphylococcus aureus analyzed by phenotyping and genotyping. J ClinMicrobiol 33:1121-1128

- Krakauer, T.and. Stiles, B.G. (2013): The staphylococcal enterotoxin (SE) family .J. of virulence 4(7): 1-15 .

- Marshall BM, and Levy SB. (2011): Food Animals and Antimicrobials: Impacts on Human Health. Clinical Microbiology Reviews 24(4):718-733 
- Matlow A, Forgie S. and Pelude L. (2012): National Surveillance of Methicillin-resistant Staphylococcus aureus Among Hospitalized Pediatric Patients in Canadian Acute Care Facilities, 1995-2007. The Pediatric Infectious Disease Journal 31(8):814-820

- Molla B, Byrne M, Abley M, and Gebreyes W. (2010): Occurrence of methicillin resistant Staphylococcus aureus (MRSA) on-farm, at slaughter and retail pork in commercial swine and implications for food safety. Presentation 93.http:// www. cvmbs. colostate.edu/mip/ crwad/2010_Food.htm.

- Moodley, A., Nielsen, S.S., and Guardabassi, L. 2011. Effects of tetracycline and zinc on selection of methicillin-resistant Staphylococcus aureus (MRSA) Sequence Type 398 in pigs Veterinary Microbiology

- Mousa, M. M.; Awad, H. A.; Yassin, M. M. and Gouda, H. I. (1993): Microbiological quality of some meat products. Vet. Med. J. 41 (31):59.

- Otter JA and French GL. (2012). (referring to MRSA in general) Community-associated meticillin-resistant Staphylococcus aureus: the case for a genotypic definition. Journal of Hospital Infection 81:143-148.

- Pu S.; Han F. and Ge B. (2009): Isolation and characterization of methicillin-resistant Staphylococcus aureus strains from Louisiana retail meats. Appl Environ Microbiol 75, 265-267.

- Quinn P.J.;Markey B.K.; Carter M.E; Donnelly W.J.; Leonard F.C. and Maguire D. (2002): Veterinary Microbiology and Microbial Disease.1 Published, Oxford: Blackwell Science Ltd. 
- Seiler, C and Berendonk TU. (2012): Heavy metal driven coselection of antibiotic resistance in soil and water bodies impacted by agriculture and aquaculture. Frontiers in Microbiology 3(399):1-10

- Smith T, and Pearson N. 2011. The Emergence of Staphylococcus aureus ST398. Vector-Borne and Zoonotic Diseases 11(4):327-339;

- Smith T.C.; Male M.J.; Harper A.L.;Kroeger J.S.; Tinkler G. P.; Moritz, E.D.; Capuano A.W. and Herwaldt L.A. (2008): Methicillinresistant Staphylococcus aureus (MRSA) strain ST398 is present in midwestern U.S. swine and swine workers. PLoS ONE 4, e4258. d pig farmers. Vet Microbiol. 128, 298-303.

- Stefani S.; Chung DR. and Lindsay JA, (2012): Meticillin resistant Staphylococcus aureus (MRSA): global epidemiology and harmonisation of typing methods. International Journal of Antimicrobial Agents 39:273-282.

- United States Department of Agriculture. National Agricultural Statistics Service(2007):Census of Agriculture. Hog and Pig Farming.

- VanCleef B.; Graveland H. and Haenen A. (2011): Persistence of Livestock-Associated Methicillin-Resistant Staphylococcus aureus in Field Workers after Short-Term Occupational Exposure to Pigs and Veal Calves. Journal of Clinical Microbiology 49(3):1030-1033

- Verbrugh J.L.; H.A.; Melles D.C.; van Belkum A. and van Wamel W.J. (2011): Immune Evasion Cluster Positive Bacteriophages Are Highly Prevalent among Human Staphylococcus aureusStrains, but They Are Not Essential in the First Stages of Nasal Colonization. Clinical Microbi- ology and Infection, 17, 343-348. http://dx.doi.org /10.1111/j.1469-0691.2010.03227. 
- Verkaik N.J.;Benard, M.;Boelens H.A.; De Vogel C.P.;Nouwen J.L.;Verbrugh H.A.; Melles D.C.; van Belkum A. and van Wamel W.J. (2011): Immune Evasion Cluster Positive Bacteriophages Are Highly Prevalent among Human Staphylococcus aureusStrains, but They Are Not Essential in the First Stages of Nasal Colonization. Clinical Microbi- ology and Infection, 17, 343-348. http://dx.doi.org /10.1111/j.1469-0691.2010.03227.

- Weese J.S.; Avery B.P.; Gow S.,; Booker C. and Reid-Smith R. (2009): Methicillin-resistant Staphylococcus aureus(MRSA) surveillance in slaugheter-age pigs and feedlot catle. In ASMESCMID Conference on methicillin-resistant staphylococci in animals.p. 47. London, UK.

- Wertheim H.F.L.;Melles D.C., Vos M.C.; van Leeuwen W.; van Belkum A.;Verbrugh, H.A. and Nouwen J.L. (2005): The Role of Nasal Carriage in Staphylococcus aureusInfections. Lancet Infectious Diseases,5,751-762.http://dx.doi.org/10.1016/S1473-3099 (05) 70295-4

- Wikler M.A.(2006): Performance standards for antimicrobial susceptibility testing: Sixteenth informational supplement. Clinical and Laboratory Standards Institute.

- WHO (World Health Organization): World Health Day 2011. Reduce Use of Antimicrobials in Food Producing Animals.

- Youssef H.;Hefnawy Y.and Abdel Rahman,H. (1985): Coagulase Positive Staphylococci in some meat products. Assuit Vet. Med. J., 15(29): 137-140.

- Zink, D. L. (1997): The impact of consumer demands and trends on food processing. Emerg Infect Dis. 3:467-9; PMID: 9366598; http://dx.doi.org/10.3201/ eid0304.970408. 
مدى تو ا جد الميكروب المكور العنقودي الذهبي المقاوم للميسثيللين المعزول من منتجات اللحوم المسوقة والأشخاص المحتكين بها بمدينة طنطا.

منى فؤاد التلاوي أمل محمود رجب جمال رجب حسب النبي نرمين فؤاد الثويري " معهز بحوث صحة الحيوان - معمل طنطا- طنطا- مصر

تم جمع ستون عينة عشوائية من اللحم المفري والبرجر والسجق (20 عينة لكل منهم) وستون عينة أخرى لمسحات من الأشخاص المتعاملين لذات عينات المنتجات من مختلف المحال والأسواق التجارية بمدينة طنطا وذلك لفحصها ميكروبيولوجيا ـ وقد أظهرت النتائج أن نسب وجود الميكروب المكور العنقودي الذهبي 60 و 20 و100\% على التوالي في العينات سابقة الذكر اما في عينات المسحات فقد اوضحت النتائج انها بنسب 40 و 40 و 100\%. وباستخدام اختبار الحساسية بينت الدراسة أن نسب نواجد الميكروب المكورالعنقودي الذهبي صاحب المقاومة للميسيثيللين 40و 40و60\% بكل من عينات اللحم المفري والبرجر والسجق على التوالي أما في عينات مسحات الاشخاص المتعاملين مع العينات التي تم تجميعها فقد كانت 40 و 5 و 15\% في نفس المنتجات على التوالي.

تم استخدام تفاعل البلمرة المنسلسل للتعرف علي جين mecA وهو الجين الأهم للتعرف على العترات المقاومة للميسيثللين بالميكروب المكور العنقودي الذهبي فقد ثبت تواجد هذا الجين في كل العترات المقاومة للميسثيللين التي تم التعرف عليها سابقا باختبارات الحساسية. هذا وتم مناقثة النتائج والتوصيات اللازمة للحد من وجود هذا الميكروب في منتجات اللحوم والمتعاملين معها. 